\title{
Campañas de promoción autónoma y de promoción reglada en Facebook: dos modalidades para comunicar en red social ${ }^{\star}$
}

\author{
José Sixto García* \\ Recibido: 19 de julio de 2012 Aprobado: 8 de septiembre de 2012
}

\begin{abstract}
Resumen
En este artículo analizamos, en primer lugar, la evolución de las audiencias de Facebook hasta su consolidación como la red social más importante del mundo, con más de 700 millones de usuarios. Por otro lado, mediante el análisis de contenido y el monitoreo de medios, describimos todas las posibilidades comunicativas que permite esta red para la interacción entre los públicos. Lo más destacado de la investigación es que mediante la observación participante, catalogamos todos los mecanismos que ofrece la red para la implementación de campañas de marketing en red. Los resultados identifican dos posibilidades diferentes: las modalidades de promoción autónomas fundamentadas en el marketing viral y las de promoción reglada que suponen un abono de dinero por parte de los demandantes.
\end{abstract}

Palabras clave: Facebook, marketing viral, promoción autónoma, promoción reglada.

* $\quad$ Esta investigación se enmarca en los proyectos de investigación financiados por la Universidad de Compostela.

** Licenciado en Periodismo de la Universidad Santiago de Compostela donde también ha obtenido el diploma de estudios avanzados y realiza su tesis sobre Marketing y Comunicación. Entre sus líneas de Comunicación se destacan la Comunicación Institucional / organizacioal y el Marketing. Actualmente se desempeña como investigador y profesor de la Facultad de Ciencias de la Comunicación de la Universidad de Compostela, España. Correo electrónico: josesixtogarcía@hotmail.com 


\title{
Autonomous and Regulated Campaigns in Facebook, two modalities to Communicate on a Social Network
}

\begin{abstract}
In this article, the evolution of Facebook audiences is analyzed until its consolidations as the most important social networks of the world, with more than 700 million users; on the other hand, through the analysis of content and the monitoring of media, all communicative possibilities which allow this network for interaction among different audiences are described. The most outstanding fact of this research is that through the participating observation, all mechanisms offered by the network for implementing marketing campaigns in the network are classified. The results identify two different possibilities: autonomous promotion based on the viral marketing and the ones of ruled promotion which suppose a payment by the customers.
\end{abstract}

Key words: Facebook, viral marketing, autonomous promotion, rules promotion 


\section{Introdución: o camiño do éxito}

Facebook foi creada en 2004 por Mark Zuckerberg, un estudante de 20 anos que pretendía manter conectados e contactados os compañeiros da Universidade de Harvard, coa axuda de Dustin Moskovitz e Chris Hughes. En orixe baseouse no costume tipicamente americano de entregar aos recén chegados o denominado facebook ou libro de caras coas fotografías, nomes e perfís de todo o alumnado para que os estudantes puidesen relacionarse entre si. Polo tanto, a súa utilización estaba restrinxida ao estudantado desa Universidade e o acceso, a diferenza de na etapa actual, só se permitía mediante invitación.

En abril de 2004 Facebook comezou a ampliar o seu público obxectivo e estendeuse a outras universidades estadounidenses. En setembro dese mesmo ano iniciou unha táctica de expansión entre universidades, colexios maiores e institutos de todo o país, Canadá, Reino Unido, Irlanda, México, Porto Rico, Australia e Nova Zelanda, de xeito que a finais de 2005 xa tiña presenza nunhas 800 universidades, 2.000 colexios maiores e 25.000 institutos. Ao ano seguinte -en 2006- continuou expandíndose en India, Alemaña e Israel, en 2007 consolidouse no resto de Europa e de aí en todo o planeta:

Táboa 1. Aumento de visitantes a Facebook

\begin{tabular}{|l|c|c|c|}
\hline \multicolumn{2}{|c|}{ Progresión do aumento de visitantes a Facebook (en miles 000) } \\
\hline Rexión & Xuño 2007 & Xuño 2008 & $\begin{array}{c}\text { Aumento } \\
\text { porcentual }\end{array}$ \\
\hline Total & 52.167 & 132.105 & $153 \%$ \\
\hline Norteamérica & 35.698 & 49.248 & $38 \%$ \\
\hline Europa & 8.751 & 35.263 & $303 \%$ \\
\hline Asia & 3.712 & 20.712 & $458 \%$ \\
\hline Oriente Medio -África & 2.974 & 14.951 & $403 \%$ \\
\hline América Latina & 1.033 & 11.931 & $1055 \%$ \\
\hline
\end{tabular}

Fonte: elaboración propia a partir dos datos de comScore World Metrix
A consolidación da rede en Europa produciuse dunha maneira fugaz. Nun ano - de febreiro de 2008 a febreiro de 2009- Facebook pasou dos 24 millóns de usuarios aos case 100 millóns, o que supón un aumento porcentual do 314\%. Conseguiu situarse á cabeza das redes sociais máis visitadas na gran maioría dos países europeos, desbancando a Myspace. O crecemento é especialmente notable en España -medra un 999\% e desmarca do primeiro posto a Tuenti-, que só é superada por Italia, onde se rexistra o maior crecemento europeo $-2.721 \%$ - e pasa dos 382.000 usuarios en febreiro de 2008 aos $10 \mathrm{mi}-$ llóns ao ano seguinte:

Táboa 2. Aumento de usuarios de Facebook en Europa

\begin{tabular}{|l|c|c|c|c|}
\hline \multicolumn{1}{|c|}{ Crecemento de usuarios de Facebook en Europa (en miles 000) } \\
\hline País & Febreiro-2008 & $\begin{array}{c}\text { Febreiro } \\
2009\end{array}$ & $\begin{array}{c}\text { Aumento } \\
\text { porcentual }\end{array}$ & $\begin{array}{c}\text { Posición no } \\
\text { ranking das } \\
\text { redes sociais }\end{array}$ \\
\hline Europa & 24.118 & 99.776 & $314 \%$ & 1 \\
\hline Reino Unido & 12.957 & 22.656 & $75 \%$ & 1 \\
\hline Francia & 2.217 & 13.698 & $518 \%$ & 1 \\
\hline Turquía & Non existía & 12.377 & & 1 \\
\hline Italia & 382 & 10.764 & $2.721 \%$ & 1 \\
\hline España & 515 & 5.662 & $999 \%$ & 1 \\
\hline Alemaña & 680 & 3.433 & $405 \%$ & 4 \\
\hline Bélxica & 327 & 2.308 & $607 \%$ & 1 \\
\hline Suecia & 1.211 & 2.298 & $90 \%$ & 1 \\
\hline Dinamarca & 533 & 2.022 & $279 \%$ & 1 \\
\hline Suíza & 282 & 1.690 & $499 \%$ & 1 \\
\hline Noruega & 819 & 1.479 & $81 \%$ & 1 \\
\hline Finlandia & 555 & 1.341 & $142 \%$ & 1 \\
\hline Holanda & 236 & 1.031 & $337 \%$ & 2 \\
\hline Austria & 112 & 663 & $491 \%$ & 2 \\
\hline Irlanda & 203 & 512 & $153 \%$ & 2 \\
\hline Rusia & 117 & 478 & $309 \%$ & 7 \\
\hline Portugal & 72 & 193 & $169 \%$ & 3 \\
\hline
\end{tabular}

Fonte: elaboración propia a partir dos datos de comScore World Metrix 
Con todo, o crecemento en Europa non só se reflicte no aumento do número de usuarios, senón tamén na media de minutos que estes pasaron en Facebook sobre o total dos que estiveron navegando pola rede e conectados a algunha rede social. O ascenso foi do $3 \%$ no primeiro caso e do $18,1 \%$ no segundo, o que volve evidenciar a hexemonía de Facebook fronte ás outras redes:

Táboa 3. Minutos de conexión a Facebook

\begin{tabular}{|l|c|c|c|}
\hline \multicolumn{3}{|c|}{$\begin{array}{c}\text { Porcentaxe de minutos durante os que os usuarios } \\
\text { están conectados a Facebook }\end{array}$} \\
\hline & $\begin{array}{c}\text { Febreiro } \\
2008\end{array}$ & $\begin{array}{c}\text { Febreiro } \\
2009\end{array}$ & $\begin{array}{c}\text { Aumento } \\
\text { porcentual }\end{array}$ \\
\hline $\begin{array}{l}\text { Con respecto ao total } \\
\text { de minutos conecta- } \\
\text { dos a Internet }\end{array}$ & $1,1 \%$ & $4,1 \%$ & $3 \%$ \\
\hline $\begin{array}{l}\text { Con respecto ao total } \\
\text { de minutos conecta- } \\
\text { dos a redes sociais }\end{array}$ & $12,3 \%$ & $30,4 \%$ & $18,1 \%$ \\
\hline
\end{tabular}

Fonte: elaboración propia a partir dos datos de comScore World Metrix

Entre as razóns fundamentais do éxito desta rede e da súa masiva expansión pensamos que se atopan as seguintes:

1. A toma de decisións estratéxicas acertadas como a primeira orientación ao segmento universitario.

2. O esforzo por garantir a veracidade da identidade dos membros.

3. O desenvolvemento continuo de melloras e novas aplicacións e funcionalidades que aportan valor ao usuario.

4. A tradución do servizo á lingua de cada país.
Táboa 4. Relación dos cinco países con maior número de visitas e posición no ranking estatal

\begin{tabular}{|c|c|}
\hline \multicolumn{2}{|c|}{ Facebook } \\
\hline Países & Ranking \\
\hline Indonesia & 1 \\
\hline Filipinas & 1 \\
\hline Malasia & 1 \\
\hline Singapur & 1 \\
\hline Estados Unidos & 2 \\
\hline
\end{tabular}

Fonte: elaboración propia a partir dos datos de Alexa.com (a 18-02-2010)

\section{Metodoloxía da investigación}

$\mathrm{Na}$ investigación que resume este artigo empregamos tres técnicas de investigación diferentes e á vez complementarias. Dúas delas son técnicas de carácter cuantitativo -a análise de contido e o monitoreo de medios- e a terceira é unha técnica de carácter cualitativo -a observación participante como usuarios-. A combinación de técnicas cualitativas con cuantitativas responde, pois, á chamada triangulación metodolóxica, que dota a investigación de maior calidade e rigor científicos.

A análise de contido foi empregada para determinar as modalidades comunicativas que os usuarios poden realizar na rede e cuantificar os mecanismos de interacción entre os participantes. Esta técnica foi axudada do monitoreo de medios, mediante o que foi posible identificar as pautas e os modelos de comportamento das audiencias. Con respecto á observación participante cómpre salientar que a técnica foi recorrida durante toda a investigación, no sentido de usuarios que á parte de analizar o contido participan nel como usuarios comúns, pero foi especialmente relevante á hora de programar, deseñar e compoñer modelos de marketing e publicidade seguindo as opcións que permite a rede aos anunciantes reais. 
Doutra banda, habemos de mencionar tamén o emprego de bases de datos estatísticas e medidores de audiencia en Internet para o estudo da evolución da popularidade da rede e a indagación sobre os perfís de usuario.

\section{Resultados da investigación: posibilidades comunicativas en Facebook}

\subsection{A idiosincrasia de rede social}

Facebook ofrece posibilidades comunicativas comúns con calquera outra rede social, pero amais inclúe outras que son exclusivas dela e que son consideradas como elementos de valor engadido polos usuarios, o que axuda a fortalecer e consolidar o seu éxito. Precisamente xa en maio de 2004 a compañía abriu a plataforma aos desenvolvedores externos para que puidesen crear aplicacións sinxelas, divertidas e intuitivas -enviar copas aos amigos, parabéns ou bicos virtuais- soportadas por Facebook e que operasen dentro do sistema. Esta decisión estratéxica permitiu a aparición de numerosos programas simples feitos por terceiros que posibilitan a co- municación distinta e innovadora.

Trátase dun movemento que marca tendencia dentro do mercado das redes sociais, facendo que se consoliden como plataformas unha serie de funcionalidades básicas que ofrecen estes servizos de OSN e desprazando a xeración de valor a outros elementos de servizo (Fumero e García, 2008). Nesa mesma liña, tamén modificaron a páxina de inicio para os usuarios, incluíndo unha aplicación de diario colectivo que sería decisiva na páxina e que permite coñecer o que están facendo os contactos en tempo real.

Facebook é unha rede de ocio que ofrece posibilidades propias como a creación de tests para compartir co resto de usuarios, creación de comunidades de fans de calquera tipo de circunstancia ou persoa, opción de sinalar que ao usuario lle gusta o que outros realizan ou publican, creación de grupos, suxestións de páxinas e posibles coñecidos, xogos e aplicacións varias, titulares de última hora sobre a actividade dos amigos, interacción co usuario para que retome o contacto con outros membros, cuantificación

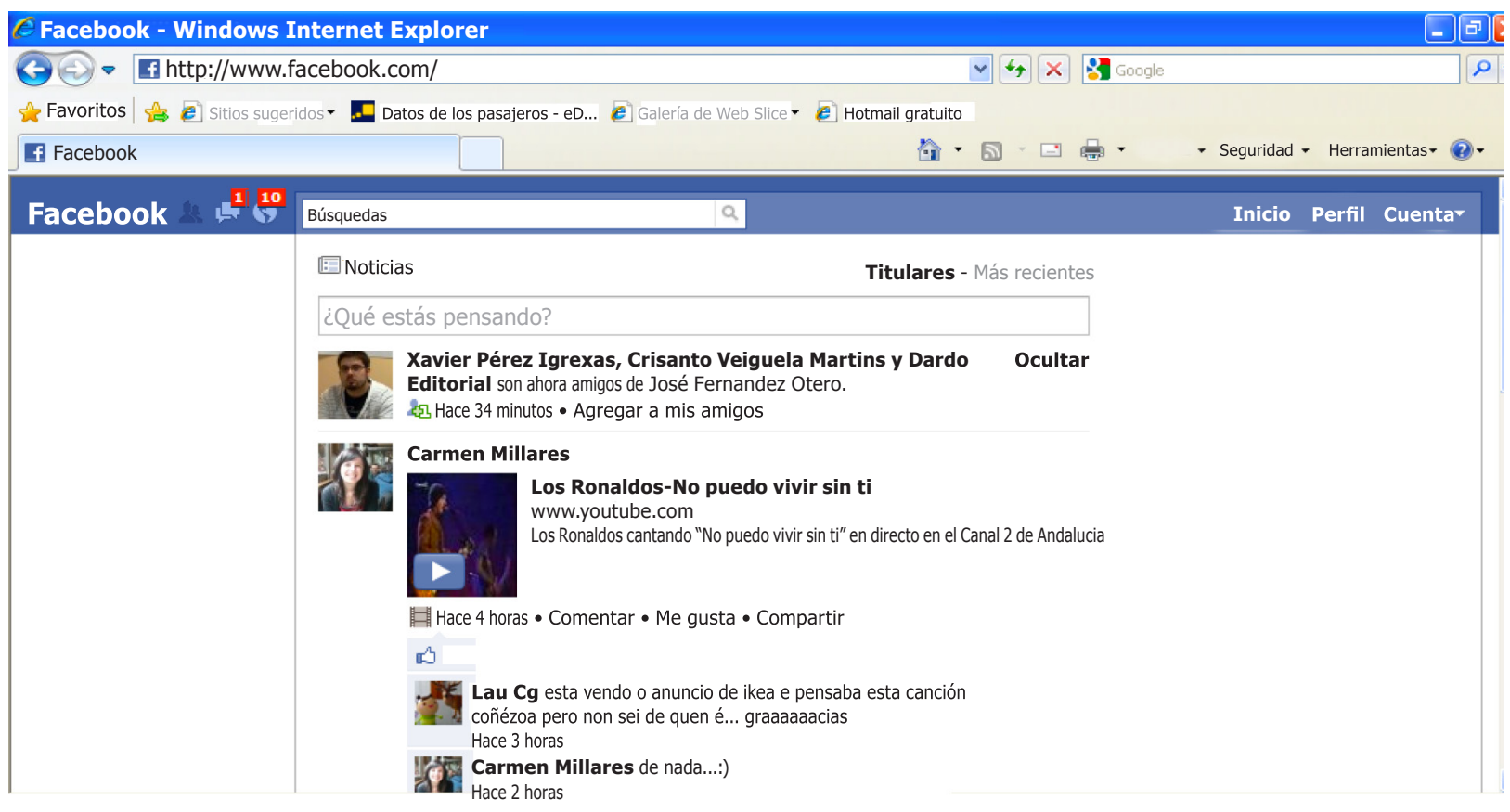

Imaxe 1. Páxina de inicio de Facebook 
de amigos comúns con outro membro da comunidade da rede ou creación e vinculación a grupos de usuarios.

Comparte con outras redes de éxito os trazos de permitir crear eventos e invitar amigos; subir fotos, vídeos, eventos ou enlaces; notificar a asistencia a un evento determinado; configurar álbums de fotos; compartir cos demais o que un realiza a tempo real -o estado-; un chat para falar en tempo real cos contactos conectados; publicar datos sobre o perfil do usuario, sendo este quen decide que e cando facelos públicos; buscar novos amigos ou eventos, comentar estados ou calquera outra publicación; avisar dos aniversarios dos demais membros ou configurar a conta, a privacidade ou as aplicacións.

\subsection{Opcións para o emprego de Facebook como instrumento de marketing 2.0}

En maio de 2007 Facebook decidiu comezar a incluír publicidade nas súas páxinas e abriu a Application Programing Interface (API) para poder vender publicidade a terceiros e descentralizar a explotación e a operación dela. Antes dun ano, en xaneiro de 2008, a aplicación xa estaba dispoñible en inglés, español e alemán.

O perfil de usuario de Facebook en España responde a unha muller de entre 18 e 24 anos con estudos medios ou superiores, que non ten fillos e que se conecta á rede desde a casa ou o lugar de estudo. Porén, se tomamos como fonte a propia rede social, a audiencia é fundamentalmente masculina e os usos por franxas xeracionais son os que seguen. Aínda así, sempre gozan de maior credibilidade os datos dos medidores externos que os das propias redes, aínda no caso de que os fagan públicos (gráfica 1).

Malia todo, comprobaremos no que vén que o perfil de usuario tipo de Facebook non é excesivamente relevante para a execución das campañas de marketing, posto que a rede ofrece mecanismos exhaustivos para segmentar o público de xeito moi concreto e perfilado, o que permite a comunicación cos consumidores potenciais de forma directa.

Gráfica 1. Audiencia de Facebook segundo o medidor interno

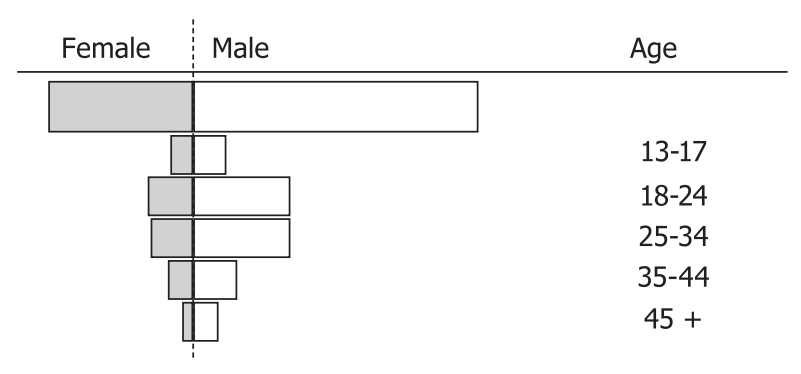

Fonte: Facebook

\subsubsection{Campañas de promoción autónoma e campañas de promoción regrada}

Froito do traballo exploratorio realizado nesta rede social, discernimos dous tipos diferentes de desenvolver unha campaña de marketing en Facebook, que denominamos como segue:

1. Campaña de promoción autónoma: grazas ás posibilidades comunicativas que ofrece Facebook para crear páxinas, eventos, grupos ou calquera outro tipo de aplicación o usuario pode promocionar nelas o produto que desexe e dalo a coñecer ao resto de usuarios, intentando que tamén para eles sexa valioso. É o usuario fundador quen selecciona o público obxectivo ao que quere dirixirse de entre a súa rede de amigos (no caso das páxinas poden sumarse seguidores sen necesidade de aceptalos como amigos), aos que tamén pode demandar colaboración para que expandan o anunciado entre os seus contactos e así sucesivamente. Facebook non participa en absoluto no proceso -sempre e cando se respecte a legalidade - e son os propios usuarios os que mediante unha estratexia de marketing viral dan a coñecer o produto uns aos outros, o que significa que o seu custe é cero. 


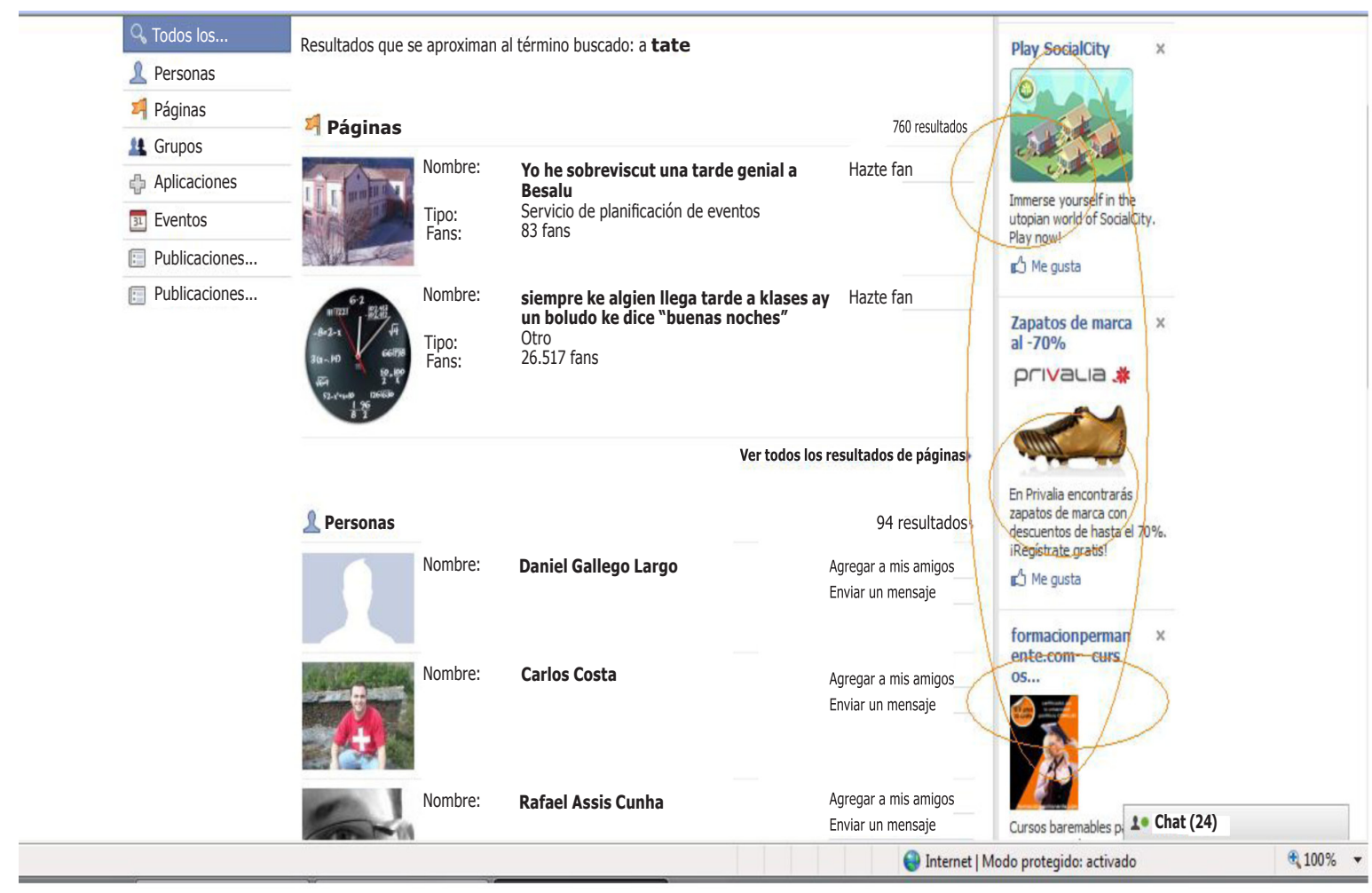

Imaxe 2. Anuncios en Facebook

2. Campaña de promoción regrada: neste caso o usuario que desexa promocionar un produto a través das rede sométese aos canons que Facebook ten establecidos para estes efectos. Esta práctica xa non é de balde, pero a cambio ofrece toda unha serie de posibilidades para facer eficaces os anuncios e adecuarse ao público nicho. Analizamos de seguido todas as súas particulares.

Facebook ofrece un amplo sistema para que sexan os propios usuarios os que creen os seus anuncios e os fagan chegar ao target que lles interesa'. Este sistema está dispoñible na rede social e é máis explícito e transparente que o de Google, por exemplo. A propia rede social practica marketing on line desde o momento en que intenta convencer os usuarios para que elaboren un anuncio e faino utilizando os elementos que

1 De feito, o lema do apartado de publicidade da rede social Facebook é: "chega ao público que queres e conéctao coa túa empresa". lle confiren valor a Facebook tales como que a rede conta con millóns de usuarios, que é posible confeccionar anuncios de texto e con imaxes ou que se permite o seguimento da rendibilidade.

Segundo a información que consta na propia rede social, os anuncios de Facebook están pensados para presupostos inferiores aos 30.000 dólares mensuais. Os anuncios móstranse na columna dereita das páxinas de Facebook dentro dun espazo reservado para publicidade que pode incluír ata tres anuncios. Existe tamén a posibilidade de que albergue un anuncio de Facebook e un banner publicitario, pero neste caso, o banner aparecerá sempre debaixo do anuncio de Facebook.

O usuario non ten posibilidade de elección da franxa en que aparecerá o seu anuncio, á parte que polo de agora a páxina de inicio, situada á dereita das Noticias, só está dispoñible para un grupo limitado de anunciantes que manteñen contacto directo co equipo comercial da rede, 
segundo datos da propia compañía. Porén, tamén avanzan que a medida que ese espazo vaia evolucionando e mellorando, proporcionarán máis detalles relativos á súa dispoñibilidade.

Para determinar que anuncios se mostran, o sistema de Facebook emprega un algoritmo que calcula cal é o anuncio con mellores resultados en función de factores como o rendemento histórico e a puxa. Esta puxa necesaria para gañar a poxa de anuncios flutúa a medida que o sistema obtén información sobre un anuncio concreto baseándose no seu rendemento real e a medida que cambia o grupo de anuncios competidores.

Por outra parte, pode ocorrer que os anuncios desta rede social para páxinas e eventos mostren historias sobre accións que realizaron os amigos do usuario en relación cos anuncios que o usuario ve. Estas historias só se mostran aos amigos e respéctase a configuración de privacidade definida na conta. Facebook tamén permite consultar a relación de anuncios mostrados a un membro da rede durante o pasado próximo.

O usuario que se decida a crear un anuncio en Facebook necesitará cando menos algún dos seguintes elementos:

1. O enlace. É necesario no caso de querer promocionar algunha páxina web ou algún dos produtos de Facebook como unha páxina, unha aplicación, un grupo ou un evento.

2. O texto publicitario. Desde a rede insisten na redacción da anuncios claros e concisos enfocados ao público obxectivo. O título pode abranguer ata 25 carácteres e o texto ata 135 como máximo.

3. A foto. O tamaño da imaxe modificarase para adaptala a un rectángulo de 110 píxeles de anchura por 80 píxeles de altura. A rede fai de novo fincapé en que a imaxe sexa atractiva e relevante, apropiada para o produto promocionado e adecuada ao público nicho.
A elaboración do anuncio por parte do usuario realízase en catro pasos:

1. Deseño do anuncio. Nesta primeira fase o usuario debe proporcionar a web que quere promocionar, o título e o texto do anuncio e engadir unha fotografía -isto último é opcional-.

2. Definición do público obxectivo. Por defecto, os anuncios de Facebook diríxense a usuarios cunha idade mínima de 18 anos, aínda que é posible axustar estes parámetros de segmentación. Con respecto á localización, a rede emprega a dirección IP e a información do perfil do usuario para determinar a súa situación xeográfica. Facebook ofrece a posibilidade de segmentar o público dunha maneira precisa en función das seguintes variables:

a. Ubicación: non só permite elixir o país, senón tamén cidades ou localizacións concretas dentro del, mesmo as que se inclúan dentro dun determinado radio de acción configurado por quilómetros.

b. Idade: o rango de franxa de idades está comprendido entre os 13 e os 64 anos, aínda que tamén é posible elixir calquera idade, malia que non sería recomendable pola indefinición que supón.

c. Data de nacemento: permite amosar o anuncio o día do aniversario do usuario.

d. Sexo: seleccionar homes, mulleres ou ambos os dous.

e. Palabras clave: igual que ocorre coa idade e a localización, as palabras clave aparecen definidas por defecto en función dos datos que os usuarios aportan nos seus perfís tales como actividades, libros, programas de televisión ou filmes favoritos, por exemplo. Porén, igual que ocorría cos 
parámetros xeracionais e xeográficos, permítese a modificación destes datos e a selección dos outros ítems xa predefinidos pola rede.

f. Formación académica: é posible segmentar entre usuarios con todos os diferentes niveis de formación: con estudos universitarios, universitarios ou alumnado de escola secundaria.

g. Lugares de traballo: dáse opción de escoller unha empresa, unha organización ou calquera outro lugar de traballo.

h. Relación ou situación sentimental: diferenza entre membros solteiros ou solteiras, os que teñen unha relación, comprometidos ou comprometidas e casados ou casadas.

i. Inclinación sexual: homes ou mulleres.

j. Idiomas: permite seleccionar o idioma.

En función dos parámetros de segmentación seleccionados, a aplicación indica o número exacto de usuarios aos que se vai ofrecer o anuncio. Por exemplo, no caso do noso anuncio de proba que configuramos chegaría a 3.296.740 usuarios maiores de 18 anos, homes e mulleres que viven en España, falan español e con todos os posibles niveis de formación académica.

3. Campañas e fixación de prezos. Facebook non fixa ningún prezo preestablecido para os seus anuncios, simplemente que os que pertencen a unha mesma campaña de marketing comparten o presuposto diario e a frecuencia de circulación. Para o pagamento dos anuncios cómpre atender aos seguintes campos:

a. Divisa da conta: Facebook ofrece dá a opción de escoller para pagar a conta entre 15 moedas diferentes: dólar estadounidense, dólar canadense, euro, libra esterlina, dólar australiano, ien xaponés, lira turca, bolívar venezolano, peso colombiano, coroa noruega, coroa sueca, coroa danesa, peso chileno, dólar de Hong Kong e franco suízo.

b. Nome da campaña.

c. Presuposto diario: débese indicar a cantidade máxima que o usuario quere gastar por día, tendo en conta que o mínimo é un euro -no caso de facer o pagamento nesta moeda ${ }^{2}$.

d. Frecuencia de circulación: a circulación do anuncio pode configurarse para que se realice de maneira ininterrompida desde o momento da súa creación ou ben seleccionar datas concretas.

e. Elección entre pago por clip (CPC) ou pago por impresións ou visualizacións (CPM): no primeiro caso o usuario deberá puxar pola cantidade que estea disposto a pagar por cada clic que reciba o seu anuncio; en cambio, co modelo de pago por impresións a puxa ha de facerse en función do que o usuario estea disposto a pagar por cada mil impresións do seu anuncio. En ambos os dous casos Facebook mostrará o anuncio no espazo publicitario da rede, sempre baixo a premisa de que o usuario nunca aboará máis polo anuncio que o previsto no presuposto diario, que sempre ha de ser como mínimo dúas veces o CPC ou CPM especificado.

2 Se se selecciona o pagamento en dólar estadounidense o mínimo tamén é un dólar. En lira esterlina tamén unha lira e en franco suízo tamén un franco. Noutras divisas hai variacións en función do valor da moeda, por exemplo, no caso do ien xaponés a inversión mínima diaria é de 100 iens. 
f. Puxa máxima: representa a cantidade máxima que o usuario está disposto a satisfacer por cada clic ou por cada mil visualizacións, de xeito que nunca pagará unha cantidade superior a esta puxa máxima, aínda que si é posible pagar menos. Facebook mostra tamén cales son as puxas recomendadas, é dicir, as cantidades mínimas e máximas das puxas doutros anunciantes para o grupo demográfico obxectivo previamente seleccionado. En calquera caso, hai que ter en conta que canta máis alta sexa a puxa, maiores serán as posibilidades de mostra do anuncio e, aínda así, recomendan axustala de cando en vez para manter a competitividade do anuncio na poxa ou mesmo experimentar con diferentes anuncios e públicos obxectivos para seguir mantendo vivo o interese.

g. Estimación: en función do presuposto diario e da puxa máxima, Facebook realiza unha estimación do número de clics ou visualizacións por día que recibirá un anuncio determinado. Por exemplo, no caso do noso suposto anuncio ficticio, cun presuposto diario de 100 euros e unha poxa máxima de 0,14 euros, a estimación é de 714.000 visualizacións por día ou, mediante o sistema $\mathrm{CPC}$, cunha poxa máxima de 0,40 euros, de 250 clics diarios. Amosámolo na imaxe 3.

4. Revisión e abono das cotas. O derradeiro paso na creación de anuncios en Facebook por parte dos usuarios pode dividirse en dous subapartados:

a. En primeiro lugar, a fase de revisión e comprobación de que todos os datos incorporados son correctos ou, de non ser así, a opción para poder volver atrás e modificalos.

\section{Vista previa del anuncio:}

Nombre de anuncio:

Público objetivo:

Campaña:

Tipo de puja:

Puja:

Presupuesto diario:

Duración:

\section{Sixto \\ Isto é un anuncio de proba de José Sixto \\ \& Me gusta \\ A José Sixto García le gusta esto.}

\section{Sixto:}

Este anuncio se dirige a usuarios:

- que viven en España

- que tienen 18 años o más

- que hablan Español (España)

Yo (nueva campaña)

CPC

\section{$€ 0,40$ EUR por clic}

$€ 100,0$ EUR por día

Este anuncio estará en circulación indefinidamente
Imaxe 3. Realización dunha simulación de anuncio en Facebook

b. A segunda subfase consiste no abono das cantidades establecidas para facer definitiva a incorporación do anuncio á rede social. Cómpre encher unha serie de campos con información relativa á tarxeta de crédito coa que se vaian aboar os pagamentos, tales como o nome e apelidos, o número da tarxeta de crédito, a data de nacemento ou o enderezo de facturación

Asemade contémplase a posibilidade de que o usuario posúa un cupón para trocar. Neste caso, é preciso introducir o código do cupón que será utilizado en troques de pasar os cargos á tarxeta de crédito ata que o cupón caduque ou se consuma por completo. Os códigos de cupón actívanse a través do sistema de anuncios en liña de Facebook e despois convértense en crédito publicitario que se pode trocar por anuncios. 


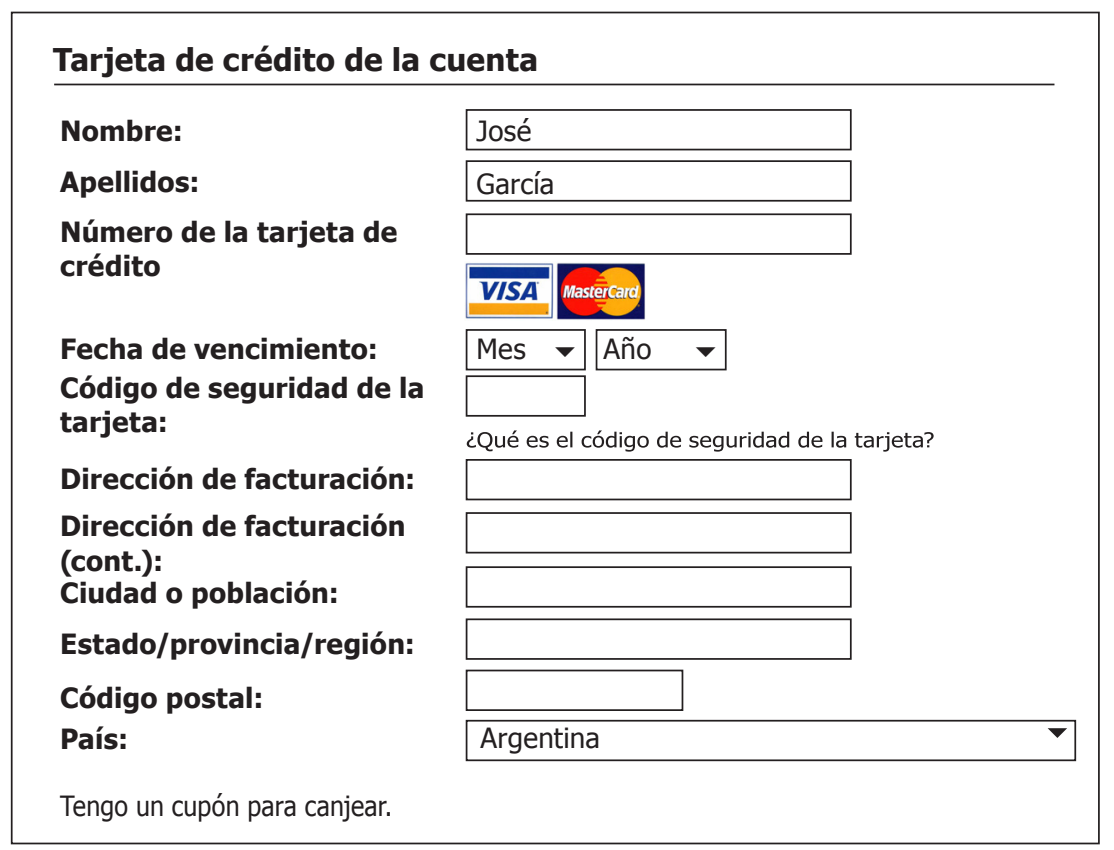

Imaxe 4. Abono de cotas publicitarias en Facebook

Esta rede social proporciónalle ao usuario un decálogo sobre boas prácticas recomendadas para elaborar anuncios que teñan éxito. Compóñeno os seguintes consellos:

1. Identificación dos obxectivos publicitarios.

2. Segmentación e público obxectivo.

3. Segmentación das palabras clave.

4. Facer destacar o produto mediante textos claros, concisos e orixinais.

5. Simplicidade do anuncio e fácil de ler, empregando oracións simples, curtas e sen erros gramaticais.

6. Animar os usuarios a actuar con expresións do tipo 'merca', 'rexístrate', 'adquire' ou 'non o penses máis'.

7. Utilizar unha imaxe.
8. Páxinas de destino adecuadas onde atopar directamente o produto anunciado, posto que se o usuario non atopa a información que busca facilmente, o máis probable é que remate por abandonar o sitio web de destino.

9. Non perder de vista a experiencia do usuario.

10. Avaliar o rendemento da campaña e facer os cambios oportunos. Un indicador para coñecelo é a taxa CTR (click through rate) que indica o número de usuarios que fixeron clic nun anuncio dividido polo número de visualizacións. Na conta do usuario tamén se poden consultar os clics e as impresións do anuncio, así como o termo medio de CPM e CPC. Co paso do tempo o usuario observará que funciona e que non ou non tan ben, de xeito que poderá modificar a segmentación para que sexa menos restritiva ou acoutala máis se en orixe era demasiada ampla. Outra opción suxerida consiste na modificación do 
anuncio para facilitar o recoñecemento do produto ou da marca.

Do mesmo xeito, Facebook relaciona outros doce erros comúns dos anuncios, que poden ser causa incluso do seu rexeitamento:

1. Todas as palabras están escritas en maiúsculas. No título está permitido comezar con maiúscula todas as palabras, pero senón deben limitarse a cando o seu uso é o correcto.

2. Hai palabras enteiras escritas en maiúsculas. As siglas poden aparecer en maiúscula e tamén os nomes comerciais se decote se escriben así.

3. Gramática, ortografía e/ou xerga incorrectas.

4. O texto do anuncio é inexacto. Debe incluír en todo caso o nome da empresa, organización, marca ou produto de destino.

5. Descontos e ofertas enganosos.

6. As imaxes son irrelevantes ou inapropiadas. Non se toleran imaxes subidas de ton, provocativas ou de espidos.

7. O público obxectivo non é o adecuado.

8. Destino inadecuado. A páxina de destino debe ser pertinente ao contido que se anuncia e respectar as Normas de Publicidade de Facebook. As únicas opcións de destino permitidas son páxinas web ou un destino iTunes -previamente indicado-, pero en ningún caso os arquivos en pdf, Word ou PowerPoint.

9. Estrutura das oracións. As frases deben ser correctas e estar ben redactadas, respectando tamén a puntuación. Non poden comezar no título e rematar no corpo do anuncio e os número de teléfono ou páxinas web deben incluírse ao final do texto.
10. A linguaxe dos anuncios ten que ser respectuosa co usuario e, nese sentido, está prohibida a blasfemia, a linguaxe para adultos ou a terminoloxía sexual.

11. Puntuación incorrecta. Non se permiten os signos de puntuación innecesarios ou incorrectos, senón que deben limitarse aos lóxicos e axeitados.

12. Uso de símbolos e números en lugar de palabras. O uso dos símbolos debe limitarse ao seu significado, polo que non poden utilizarse para substituír palabras.

13. Evidentemente o usuario que publica un anuncio en Facebook comprométese a aceptar as Condicións de Publicidade e a cumprir as Normas de Publicidade que son públicas no sitio web co fin de garantir un sitio web limpo e coherente e que fuxa da publicidade intrusiva. En caso de dúbida sobre algún aspecto durante a creación dos anuncios, a rede oferta un formulario de servizo de axuda e de información ao anunciante. Porén, do uso como usuarios, corroboramos a súa nula efectividade.

\section{Conclusións finais}

A rede social Facebook convértese polas características que ofrece e que a definen nun perfecto mecanismo ou técnica para que as organizacións ou usuarios particulares poidan desenvolver unha campaña de marketing on line. Permite definir con exactitude o público obxectivo ao que dirixirse e investir o que cada usuario estime pertinente ou mesmo facelo de maneira gratuíta mediante a creación de eventos, grupos ou aplicacións diversas.

Tanto nun caso coma noutro, o soporte que ofrece a rede pode empregarse como trampolín a un sitio web da organización, polo que a rede funcionaría como complemento da estratexia 2.0. Á 
parte, as opcións que ofrece Facebook para que os usuarios valoren determinados anuncios pode incidir favorable ou desfavorablemente nas decisións de uso ou adquisición doutros usuarios, o que supón que o produto está como nunca estivera exposto á opinión dos consumidores, que serán quen o recomenden ou rexeiten.

Finalmente, nesta última táboa sinalamos de entre todas as posibilidades comunicativas comúns ás redes sociais, as que posúe Facebook:

Táboa 5. Resumo das posibilidades comunicativas de Facebook

\begin{tabular}{|l|c|l|c|}
\hline \multicolumn{4}{|c|}{ Posibilidades comunicativas en Facebook } \\
\hline Comentarios taboleiro & $\mathrm{Si}$ & Indicar "gústame" & $\mathrm{Si}$ \\
\hline Subir fotos & $\mathrm{Si}$ & Mensaxes privadas & $\mathrm{Si}$ \\
\hline Subir vídeos & $\mathrm{Si}$ & Avisos a correo & $\mathrm{Si}$ \\
\hline Enlaces & $\mathrm{Si}$ & Interacción co usuario & $\mathrm{Si}$ \\
\hline Eventos & $\mathrm{Si}$ & Buscador amigos & $\mathrm{Si}$ \\
\hline Grupos de amigos & $\mathrm{Si}$ & Buscador contido & $\mathrm{Si}$ \\
\hline Estado & $\mathrm{Si}$ & Contador visitas & $\mathrm{Non}$ \\
\hline Titulares/novidades & $\mathrm{Si}$ & Acceso con invitación & $\mathrm{Non}$ \\
\hline Actualizacións amigos & $\mathrm{Si}$ & Enviar toques & $\mathrm{Si}$ \\
\hline Blog & $\mathrm{Non}$ & Subscricións & $\mathrm{Si}$ \\
\hline Chat & $\mathrm{Si}$ & Xogos & $\mathrm{Si}$ \\
\hline Grupos & $\mathrm{Si}$ & Aplicacións & $\mathrm{Si}$ \\
\hline Facerse fan & $\mathrm{Si}$ & Aplicación móbil & $\mathrm{Si}$ \\
\hline Elixir idioma & $\mathrm{Si}$ & Blog corporativo & $\mathrm{Non}$ \\
\hline
\end{tabular}

\section{Bibliografía final}

FUMERO, A. e GARCÍA, J. M. Redes sociales. Contextualización de un fenómeno dos-punto-cero. Telos. Cuadernos de Comunicación e Innovación, n 76 , pp. 56-68, 2008. 
